\title{
THE PRECONDITIONS FOR COMPATIBILITY OF NATIONAL PROCEDURAL ADMINISTRATIVE LAW WITH EU LAW AND THE PRELIMINARY REFERENCE PROCEDURE IN LIGHT OF RECENT JUDGMENTS FROM THE COURT OF JUSTICE OF THE EUROPEAN UNION IN BULGARIAN CASES
}

\author{
Athanase Popov*
}

\begin{abstract}
This paper shows, in a summary way, the purpose of the preliminary reference procedure before the Court of Justice of the European Union, with a special emphasis on the review of compatibility of national law with EU law. Such a review may not seem to be possible on a strict reading of the treaties, yet it is being carried out in practice. Certain preliminary references from Bulgarian courts are very good examples to that effect: Although Bulgaria is a new Member State of the EU, some of its courts' preliminary references are particularly seminal.
\end{abstract}

INTRODUCTION

I. THE BYANKOV CASE

A. The Opinion of the Advocate General ..................................... 125

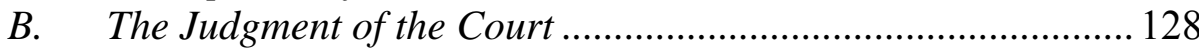

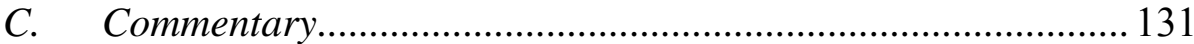

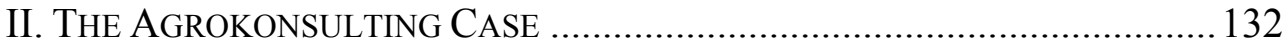

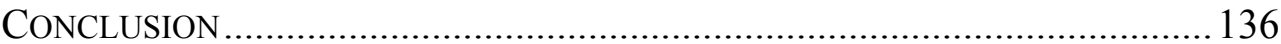

\section{INTRODUCTION}

Despite the enormous amount of academic literature on the preliminary reference procedure, the practical purpose of the latter may be explained summarily in the following way: 1) It allows a national court to ask a question on the interpretation of a provision of EU law; 2) It allows a national court to check the compatibility of a provision of national law with EU law; and 3) It allows a national court to find out if a provision of EU law has direct effect. ${ }^{1}$

\footnotetext{
* Administrator at the Court of Justice of the European Union and Ph. D. candidate on EU procedural law at the University of Luxembourg. Research fields: Actions for Annulment and Preliminary Reference Procedure; Competition Law; Public International Law and International Arbitration.

${ }^{1}$ All of these three questions were given an answer in, for instance, case C-142/12 Marinov (CJEU 8 May 2013). Bruno De Witte notes, in this regard, that "the Court does have jurisdiction to provide the national court with all the criteria for the interpretation of EU law which may enable it to assess
} 
The foregoing only applies to preliminary rulings on questions of interpretation. As far as preliminary rulings on the validity of EU legislation are concerned, the latter serves an entirely different purpose, which has very little or nothing to do with the relationship between national and EU law. Indeed, on many occasions, preliminary rulings on validity are aimed at challenging legislative measures which private applicants are precluded from challenging in, inter alia, an action for annulment due to a lack of locus standi, thus circumventing strict standing rules when applying Article 263 TFEU. $^{2}$

While preliminary rulings on the validity of EU legislation are no doubt an effective remedy, it is doubtful whether preliminary rulings on questions of interpretation are a remedy at all. Clearly, the latter is a good example of sound judicial cooperation between national judges and the Court of Justice of the European Union (hereinafter the "CJEU"), yet they are too "indirect" a remedy to be able to grant effective judicial protection to private applicants. ${ }^{3}$

Nevertheless, the fact that a provision of EU law may be interpreted in a way which could be favourable to the private applicant or that a challenged provision of national law may be declared incompatible with EU law or that a provision of EU law has a direct effect, is if not a remedy, at least a way of influencing the implementation of national law. In the end, that may turn out to be favourable to the applicant.

This paper focuses on declarations of incompatibility of national law with EU law. Most remarkably, these declarations may be targeted at both substantive and procedural (adjective) law. Two recent cases, Byankov and

whether those provisions are so compatible in order to give judgment in the proceedings before it" and that the Court is entitled to examine the compatibility of national law with EU law: "everybody knows this, but it seems better not to say it with so many words" "The Impact of Van Gend en Loos on Judicial Protection at European and National Level: Three Types of Preliminary Questions", 50th Anniversary of the Judgment in Van Gend en Loos, Conference Proceedings, Luxembourg, Office des publications de l'Union européenne, 2013, at 96-97). P. Craig and G. De Búrca express a similar idea by stating that "the dividing line between interpretation and application can be perilously thin. The more detailed is the interpretation provided by the ECJ, the closer does it approximate to application" (Paul Craig \& Gráinne De Búrca, EU Law, Text, Cases and Materials 472 (third edition, New York, Oxford University Press 2003)).

${ }^{2}$ See Athanase Popov, La complémentarité entre les recours en annulation formés par des particuliers et les renvois préjudiciels en appréciation de validité avant comme après l'entrée en vigueur du traité de Lisbonne et l'accès au prétoire de l'Union européenne, CAHIERS DE DROIT EUROPEEN 167 (2012/1), and Vzaimnoto dopalvane mezhdu zhalbata za otmyana, podadena ot tchastni litsa, i preyuditsialnoto zapitvane za pretsenka na validnostta na akt na ES predi i sled vlizaneto $v$ sila na dogovora ot Lisabon i podobryavaneto na dostapa do pravosadie, tom VI EVROPEYSKI PRAVEN PREGLED 60 (2013).

${ }^{3}$ Julie Kaprielian, Le renvoi préjudiciel en droit de l'Union : un mécanisme assurant la protection juridictionnelle effective des individus?, n6 JURISDOCTORIA 16 (2011). 
Agrokonsulting, both of which originate from Bulgaria, a Member State of the EU since 2007, deal with the compatibility of national administrative law with EU law.

Byankov and Agrokonsulting are both seminal cases, although in the former, national procedural law was declared to be compatible with EU law, while in the latter, it was held that EU law does not preclude a national rule of jurisdiction which results in conferring on a single court all disputes of a certain kind, when the governing law is EU law. Indeed, Agrokonsulting introduces the important proviso that national rules on jurisdiction, which form part, in casu, of national administrative procedure, not be conducted in less advantageous conditions than those provided for in respect of actions under national law, and that the contested jurisdiction rule does not cause individuals procedural problems in terms of the duration of the proceedings, such as to render the exercise of the rights derived from European Union law excessively difficult.

\section{THE BYANKOV CASE}

The applicant in the main proceedings, Mr. Byankov, was a Bulgarian national. An order was imposed on him, containing a prohibition on leaving Bulgarian territory and on a passport being issued to him, adopted on the basis of Article 76(3) of the Law on Bulgarian Identity Documents (Zakon za balgarskite lichni dokumenti, "ZBLD"), in the version which was then in force. At the request of a bailiff, that measure was taken against Mr. Byankov by the Director of the Regional Directorate of the Ministry of the Interior on account of a debt, classified as considerable (that is to say, according to Bulgarian law, in excess of BGN 5,000) owed to a Bulgarian private legal person and Mr. Byankov's inability to provide adequate security. Mr. Byankov did not challenge that order before a court, and it therefore became final.

More than three years after the administrative act at issue was adopted, Mr. Byankov applied to the authority which had adopted the order for the administrative procedure to be reopened and that act to be annulled. Mr. Byankov claimed that the freedom of movement he enjoyed as a citizen of the European Union may be restricted only in the circumstances provided by European Union law. The restriction imposed on him by the 2007 order prohibiting him from leaving the territory was not, in his view, imposed on grounds of public policy within the meaning of Directive 2004/38, which was clear inter alia from the judgment the court delivered, after the adoption 
of the act at issue, in Jipa ${ }^{4}$. He argued that the restrictive measures liable to be adopted under Article 76(3) of the ZBLD could not be covered by the notion of "public policy".

The Glaven Sekretar na Ministerstvoto na vatreshnite raboti (Principal Secretary of the Ministry of the Interior), to whom Mr. Byankov's application was forwarded, examined it as an application for annulment of a final administrative act, a procedure provided in Article 99 of the Code of Administrative Procedure (Administrativno protsesualen kodeks, "APK”). The competent administrative authority rejected the application. It was stated that none of the grounds for annulment provided in Article 99(2) to (7) of the APK - the cases in which an individual is entitled to make an application for the procedure to be reopened-had been established. The applicant in the main proceedings therefore decided to bring the matter before the referring court, claiming that his application for annulment of the 2007 order should be allowed. The defendant in the main proceedings contends that Mr. Byankov's action should be dismissed, relying on the lawfulness of the prohibition on leaving the territory at issue.

In those circumstances the Administrativen sad Sofia-grad (Sofia Administrative Court) decided to stay the proceedings and to refer the following questions to the Court for a preliminary ruling:

1. In the light of the facts of the main proceedings, does the principle of sincere cooperation under Article 4(3) TEU in conjunction with Articles 20 TFEU and 21 TFEU require that a national provision of a Member State such as that at issue in the main proceedings - under which a final administrative act may be annulled in order to put an end to an infringement of a fundamental right which has been established by a decision of the European Court of Human Rights, which right is also recognised in European Union law and concerns the freedom of movement enjoyed by nationals of the Member States - must also be applied with reference to the interpretation adopted by decision of the Court... of provisions of European Union law which are relevant to the restrictions on the exercise of the aforementioned right, where the administrative act must be annulled in order to put an end to the infringement?

2. Does it follow from Articles 31(1) and (3) of Directive 2004/38 that, where a Member State has provided in its national law for a procedure for examining an administrative act which limits the right under Article 4(1) of the Directive, the competent administrative authority is required, at the request of the addressee of the administrative act, to examine that measure

\footnotetext{
${ }^{4}$ Case C-33/07 Jipa [2008] ECR I-5157.
} 
and to assess its legality with reference also to the case-law of the Court... on the interpretation of relevant provisions of European Union law governing the conditions and limitations applicable to the exercise of that right, so as to ensure that the limitation imposed on the right is not disproportionate at the time when the review decision is adopted, where the administrative act imposing the limitation is already final at that time?

3. Do the provisions of the second sentence of Article 52(1) of the [Charter] and Article 27(1) of Directive 2004/38 permit the application of a national provision which provides for the imposition of a limitation on the freedom of movement, within the European Union, of a national of a Member State, solely on account of the existence of an unsecured liability in excess of a certain amount laid down by law that is owed to a private person (a commercial company), in the context of pending enforcement proceedings for the recovery of the claim, and without regard to the possibility, provided for in European Union law, of the claim being recovered by an authority of another Member State?

\section{A. The Opinion of the Advocate General}

Mr. Advocate General Mengozzi delivered his opinion on June 21, 2012. He wrote that the third question required only a rapid assessment since recent judgements had already given sufficient clarification on the legal problem which was raised. ${ }^{5}$ To him, the third question was clearly a question on the compatibility of the prohibition on leaving the territory with the law of the European Union. ${ }^{6}$ He suggested that the answer that the Court should give to the third question should be that European Union law precludes a legislative provision of a Member State which allows an administrative authority to prohibit a national of that State from leaving that State solely on account of a debt, regarded by national law as being considerable, which he owes to a private legal person where the aim of the measure at issue is not to respond to a genuine, present and sufficiently serious threat affecting one of the fundamental interests of society and where the objective thus sought serves only economic ends. He added that in any event, even if a prohibition on leaving the territory such as that imposed on Mr. Byankov in the case in the main proceedings had been adopted in the circumstances provided for in Article 27(1) of

\footnotetext{
${ }^{5}$ Case C-249/11, Hristo Byankov v Glaven sekretar na Ministerstvo na vatreshnite raboti, (CJEU 4 October 2012), Opinion of Advocate General Mr Mengozzi delivered on June 21, 2012 (hereinafter "Opinion of Advocate General Mengozzi"), para. 19.

${ }^{6}$ See heading "A" before para. 20 and seq.
} 
Directive 2004/38, Article 27(2) of that directive precludes such a measure where it is based solely on the existence of the debt without any specific assessment of the personal conduct of the person concerned and no reference is made to any threat which that conduct might constitute as regards public policy. ${ }^{7}$

Mr. Mengozzi understood the second question referred to the Court for a preliminary ruling as meaning that the referring court was seeking, in essence, to ascertain whether Directive 2004/38 imposes an obligation to review even in a situation where the measure restricting the freedom of movement of the citizen of the Union has become final. ${ }^{8}$ According to his analysis:

Both the wording and the purpose of Article 32 of Directive 2004/38 call for the conclusion that, contrary to what the referring court has held, the fact that an act is final is not an obstacle to its being reviewed. It would, moreover make no sense to require a review only of acts which are in any event open to appeal. ${ }^{9}$

Therefore, the second question raised by the referring court was analysed as irrelevant as regards settling the dispute. Advocate General Mengozzi continued by writing that it was apparent from the information provided by the referring court that the administrative procedure resulting in the adoption of the final individual administrative act which had not been contested before the courts may, by way of an exception, be reopened for the purposes of annulling or amending that act in the seven separate circumstances listed exhaustively in Article 99 of the APK. Of those seven circumstances, two in particular had attracted the attention of the referring court. $^{10}$

First, there was Article 99(7) of the APK. That provision allows the person to whom the administrative act at issue is addressed to apply at any time, and if appropriate to the courts, for the administrative procedure to be reopened where a judgment of the European Court of Human Rights has shown that the act at issue infringes a fundamental right contained in the ECHR. The provision is worded in such a way that it expressly relates solely to judgments of the European Court of Human Rights. No equivalent provision exists in relation to judgments of the Court of Justice. However, Advocate General Mengozzi wrote that such a provision was not necessary since, in contrast to the law deriving from the ECHR, European Union law is distinguished by its two essential qualities: precedence (also called

\footnotetext{
${ }^{7}$ Opinion of Advocate General Mengozzi, para. 30.

${ }^{8}$ Ibid, para. 31.

${ }^{9} \mathrm{Ibid}$, para. 35 .

${ }^{10} \mathrm{Ibid}$, para. 42
} 
"supremacy" or "primacy") and direct effect. ${ }^{11}$ However,

In view of the special characteristics of the European Union legal order and the particular nature of the mechanism of a reference for a preliminary ruling, the obligations incumbent on national courts as regards the circumstances in which they must review, on the ground of an infringement of European Union law, the legality of an administrative act which has become final must be envisaged in a totally different way from a situation where the alleged illegality derives from a judgment of the European Court of Human Rights. ${ }^{12}$

It was clear from the relevant national provisions as presented by the referring court that the national law provides another option for reopening the administrative procedure which is different from that exclusively based on the case-law of the European Court of Human Rights and which was therefore more relevant in the present case. Article 99(1) of the APK provides that an administrative act which has become final may be annulled or amended if there is an essential infringement of one of the conditions governing its legality. Precisely because of the special characteristics of European Union law, the national concept of "essential infringement of legality" must be construed as including cases in which the act is contrary to European Union law. However, unlike Article 99(7) of the APK, the ground for reopening the procedure which is provided for in Article 99(1) of the APK cannot be invoked at any time by the person to whom that act relates. On the contrary, the annulment or amendment of an administrative act which has become final is, in that case, hedged round by strict conditions with regard to the power of initiative and the time-limit. Indeed, only the administrative authority which adopted the act, the public prosecutor or the national ombudsman can take a decision - or make a request - to annul or amend that act, and do so within one month from the adoption of the act. What is more, it was apparent from the information provided by the referring court that the ground for reopening the administrative procedure provided by Article 99(1) of the APK was conceived of as a "right" pertaining to the administration. The appropriateness of implementing was left to the discretion of the authorities with the power to initiate the annulment or amendment of the act; those authorities therefore had complete discretion in such circumstances and the person concerned could not exercise his own initiative and claim infringement of the substantive legality of the act which affects his personal situation. ${ }^{13}$

With regard to the time-limit, the Advocate General pointed out that

\footnotetext{
${ }^{11}$ Ibid, paras. 43-44.

${ }^{12}$ Ibid, para. 44.

${ }^{13} \mathrm{Ibid}$, paras. 45-47.
} 
the Court has held that the Member States may, on the basis of the principle of legal certainty, require an application for review and withdrawal of an administrative decision that has become final and is contrary to European Union law as interpreted subsequently by the Court to be made to the competent administrative authority within a reasonable period (Case C-2/06 Kempter [2008] ECR I-411, para. 59) The time-limit must specifically be set in a manner consistent with the principles of effectiveness and equivalence (Kempter, operative part). Mr. Mengozzi noted that under Bulgarian law, the administrative procedure may be reopened on the basis of Article 99(1) of the APK only within one month from the adoption of the act which has not been contested before the courts, a time-limit which, in his view, did not meet the requirements associated with the principle of effectiveness. ${ }^{14}$

The requirements associated with the principle of effectiveness did not appear to be met also with regard to the authorities empowered to initiate the reopening of the administrative procedure. Where infringement of the substantive legality of an administrative act which has become final and which has not been contested before the courts was the result of that act being contrary to European Union law, the person to whom the act was addressed could not apply for the administrative procedure to be reopened (see above). Thus, hedged round by over-restrictive conditions relating to the time-limit and the bodies which can lodge the application, the ground for reopening the administrative procedure provided for in Article 99(1) of the APK, by rendering the exercise of rights conferred by European Union law excessively difficult or impossible in practice, did not make it possible to safeguard adequately the rights which individuals derive from European Union law. Hence, it was for the national court to draw from this all the appropriate conclusions for the dispute in the main proceedings in order to rule on the application brought before it by the applicant in the main proceedings for annulment of the order refusing to reopen the administrative procedure. $^{15}$

\section{B. The Judgment of the Court}

The Court answered the third question referred to it in the following manner: European Union law must be interpreted as precluding the application of a national provision which provides for the imposition of a restriction on the freedom of movement, within the European Union, of a

\footnotetext{
${ }^{14}$ Ibid, para. 57.

${ }^{15}$ Ibid, paras. 58-59.
} 
national of a Member State, solely on the ground that he owes a legal person governed by private law a debt which exceeds a statutory threshold and is unsecured. $^{16}$

According to the Court's analysis, the first and second questions must be understood, in essence, as seeking to ascertain whether, in circumstances such as those of the case before the referring court, European Union law must be interpreted as precluding legislation of a Member State under which an administrative procedure that has resulted in the adoption of a prohibition on leaving the territory such as that at issue in the main proceedings, which has become final and has not been contested before the courts, may be reopened - in the event of that measure being clearly contrary to European Union law-only in circumstances such as those exhaustively listed in Article 99 APK, despite the fact that such a prohibition continues to produce legal effects with regard to its addressee. ${ }^{17}$

In order to answer the first and second questions, the Court reminded that it is settled case-law that, in the absence of relevant European Union rules, it is, under the principle of procedural autonomy of the Member States, for the domestic legal system of each Member State to regulate the legal procedures designed to ensure the protection of the rights which individuals acquire under European Union law, provided, however, that they are not less favourable than those governing similar domestic situations (principle of equivalence) and that they do not render impossible in practice or excessively difficult the exercise of rights conferred by the European Union legal order (principle of effectiveness). ${ }^{18}$ According to the Court, in the present case, the question which arose more particularly was whether national legislation such as that described by the referring court was compatible with the principles of effectiveness and sincere cooperation. Indeed, under such legislation, addressees of prohibitions on leaving the territory in situations such as Mr. Byankov's will never, unless they pay the sums claimed or provide adequate security, have an opportunity to have their cases reviewed, despite the manifest illegality of prohibitions on leaving the territory which are imposed on them for an unlimited period. Furthermore, since no initiative was taken to withdraw prohibitions on leaving the territory, imposed under Article 76(3) of the ZBLD, following the judgment in Jipa in particular and since a one-month period was applicable when Article 99(1) of the APK was applied, the relevant

\footnotetext{
${ }^{16}$ Case C-249/11, Hristo Byankov v Glaven sekretar na Ministerstvo na vatreshnite raboti, (CJEU 4 October 2012), operative part of the judgment.

${ }^{17}$ Ibid, para. 66.

${ }^{18}$ Ibid, para. 69.
} 
administrative bodies considered themselves to be barred from allowing a review in situations such as that at issue in the main proceedings, even though the illegality under European Union law had been confirmed by the Court's case-law. ${ }^{19}$

The Court has already acknowledged that finality of an administrative decision contributes to legal certainty, with the consequence that European Union law does not require that an administrative body be, in principle, under an obligation to reopen an administrative decision which has become final (see, to that effect, Case C-2/06 Kempter [2008] ECR I-411, paragraph 37). The Court held none the less, as in Kempter, that particular circumstances may be capable, by virtue of the principle of sincere cooperation arising from Article 4(3) TEU, of requiring a national administrative body to review an administrative decision that has become final, in particular to take account of the interpretation of a relevant provision of European law which the Court has given subsequently. In the present case, it was necessary to consider more specifically whether, in situations such as that at issue in the main proceedings, national legislation such as that described in the order for reference may be justified in order to safeguard the principle of legal certainty, having regard to the consequences that follow from such legislation for the application of European Union law and for citizens of the Union who are subject to prohibitions on leaving the territory such as the one in issue before the referring court.

According to the Court, in circumstances such as those of the main proceedings, the legislation at issue, which made no provision for regular review, maintained for an unlimited period a prohibition on leaving the territory and thereby perpetuated an infringement of the right laid down in Article 21(1) TFEU to move and reside freely within the territory of the Member States. It held that in such circumstances, a prohibition of that kind was the "antithesis" of the freedom conferred by Union citizenship to move and reside within the territory of the Member States. ${ }^{20}$

The Court concluded that, in view also of the importance which primary law accords to citizenship of the Union, national legislation such as that described in the order for reference, to the extent that it (i) prevents citizens of the Union from asserting the right conferred on them by Article 21 TFEU to move and reside freely against absolute territorial prohibitions that have been adopted for an unlimited period and (ii) prevents administrative bodies from acting upon a body of case-law whereby the Court has confirmed the illegality, under European Union law, of such

\footnotetext{
${ }^{19}$ Ibid, paras. 70-74.

${ }^{20}$ Ibid, para. 79 .
} 
prohibitions, cannot reasonably be justified by the principle of legal certainty and must therefore be considered, in this respect, to be contrary to the principle of effectiveness and to Article 4(3) TEU. ${ }^{21}$

\section{Commentary}

What is remarkable in Byankov is not only that the Court ruled that a national provision which provides for the imposition of a restriction on the freedom of movement, within the European Union, of a national of a Member State, solely on the ground that he owes a legal person governed by private law a debt which exceeds a statutory threshold, is incompatible with EU law, but also that, in such circumstances, the administrative procedure should be reopened beyond situations such as those exhaustively listed in the national code of administrative procedure. ${ }^{22}$

So, beyond a mere issue of compatibility of national substantive law with EU law, Byankov focuses on the compatibility of national procedural law with the latter. As far as substantive compatibility is concerned, the referring court could have relied on decision $n 2$ of March 31, 2011 of the Bulgarian constitutional court, which declared the substantive provisions of the ZBLD at issue to be incompatible with the Constitution (that decision predates the order for reference) ${ }^{23}$ Besides, the Varhoven administrativen sad (Supreme Administrative Court) had ruled, in its interpretative decision n 2 from March 22, 2013, that an administrative measure under the substantive provisions of the ZBLD at issue should be annulled by the courts if it contravened directive 2004/38. ${ }^{24}$

At issue was also Article 99 of the APK, which is contained in Chapter 7 of the APK entitled "Reopening of the procedure for the adoption of administrative acts", and reads:

A final individual or general administrative act which has not been contested before the courts may be [abrogated] or amended by the next-higher-ranking administrative authority or, if the administrative act was not open to challenge by way of an administrative remedy, by the authority which adopted it, where:

\footnotetext{
${ }^{21}$ Ibid, para. 81.

${ }^{22}$ Denys Simon, Obligation de rouvrir une procédure administrative définitive, EUROPE comm. 473 (décembre n12, 2012).

${ }^{23}$ That decision has been cited by the referring court at para. 9 of the order for reference, available at http://www.sac.government.bg/home.nsf/vPagesLookup/Преюдициално\%20опр.\%20по\%20дело\%2 05873/2010 bg? (Open Document, last visited July 31, 2013).

${ }^{24}$ The interpretative decision, which has been cited at para. 11 of the order for reference, available at http://www.sac.government.bg/home.nsf/vPagesLookup/Тълк.\%20p-е\%202/22.03.2011 bg? (Open Document, last visited July 31, 2013).
} 
1. there has been a material breach of one of the conditions governing its legality;

7. a decision of the European Court of Human Rights has established an infringement of the [European Convention on the Protection of Human Rights and Fundamental Freedoms signed in Rome on 4 November 1950].

The notion of "reopening of the administrative procedure" is a special feature of Bulgarian law, which allows the administration to reopen and abrogate or modify an administrative act "which has not been contested before the courts" or which was not "open to challenge by way of an administrative remedy". The reopening of the administrative procedure is not a remedy per se, but is a mere extrajudicial way of tackling illegality. Yet even that procedural legal device has to be compatible with EU law. Advocate General Mengozzi even goes as far as writing that using Article 99(1) APK is preferable to using Article 99(7) APK because "the legality of an administrative act which has become final must be envisaged in a totally different way from a situation where the alleged illegality derives from a judgment of the European Court of Human Rights" (see above).

It could be said that Mr. Mengozzi went a little bit too far in his analysis: Procedural autonomy should be limited only as far as the result of a procedural legislation is concerned. If the referring court prefers Article 99(7) APK to 99(1), wouldn't the contested act be abrogated in the same way? What was important to emphasise was that the administrative procedure must be reopened in case of breach of EU law, even if a similar legal device may not exist in other jurisdictions.

\section{The Agrokonsulting CASE}

In Agrokonsulting, the Court was required for the very first time to give a ruling on whether the principles of effectiveness and equivalence, and also the first paragraph of Article 47 of the Charter of Fundamental Rights of the European Union ("the Charter") precludes a rule of national procedure which has the consequence of concentrating before a single court disputes concerning decisions of the national authority responsible for paying agricultural aid under the common agricultural policy ("CAP"). The Administrativen sad Sofia-grad (Sofia Administrative Court, Bulgaria) considered that such specialisation in the context of those disputes could discourage, or even prevent, the individuals concerned, namely farmers, from having access to a court, which would constitute a violation of their right to an effective remedy. 
As in Byankov, the relevant legislation at issue was once again several provisions of the APK. Under Article 128 of the APK, all proceedings concerning applications for the adoption, amendment or annulment of an administrative act, or for a declaration that it is void, fall within the jurisdiction of the administrative courts. Article 133(1) of the APK provides that the proceedings fall within the jurisdiction of the Administrativen sad in whose judicial district the authority which adopted the contested administrative act has its seat. In Bulgaria, the sole authority competent to authorise or reject applications for support under the CAP schemes is the Izpalnitelen direktor na Darzhaven fond "Zemedelie" (Executive Director of the National Agriculture Fund, "the Direktor"), whose seat is in Sofia. Finally, paragraph 19 of the transitional and final provisions of the law amending and supplementing the APK provides that individual administrative acts under the law on ownership and use of agricultural land (Zakon za sobstvenostta i polzuvaneto na zemedelskite zemi, hereinafter "ZSPZZ") and its implementing decree and refusals to adopt such acts, unless enacted by the Minister for Agriculture and Food (Ministar na zemedelieto i hranite), may be challenged before the Rayonen sad (First Instance Court) in the place where the property is located, in accordance with the APK.

ET Agrokonsulting-04-Velko Stoyanov (“Agrokonsulting”) had been registered as a farmer since March 23, 2007. On May 11, 2010, it lodged an application for aid under the following aid schemes of the CAP: (i) the single area payment scheme and (ii) the complementary national payments per hectare of agricultural land. The land in question was situated in the region of Veliko Tarnovo (Bulgaria), approximately $250 \mathrm{~km}$ from the city of Sofia.

By letter of October 2, 2011, the Director refused the application on the ground that the areas declared by Agrokonsulting did not comply with the requirements of Regulation n 1122/2009. Agrokonsulting lodged an appeal against that decision before the Administrativen sad, Burgas (Bulgaria). On November 16, 2011, that court found that there was a conflict of jurisdiction, stayed the proceedings and referred the case to the Administrativen sad Sofia-grad, for a ruling on jurisdiction, on the ground that, under Article 133 of the APK, the matter was within the jurisdiction of the administrative court within whose judicial district the Direktor's seat was located, namely, Sofia.

The Administrativen sad Sofia-grad considered that the conflict of jurisdiction should be referred to the Varhoven administrativen sad (Supreme Administrative Court) (Bulgaria) but was uncertain with regard to 
the interpretation and the scope of the principles of procedural autonomy, effectiveness and equivalence. It therefore decided to stay the proceedings and to refer two questions to the Court of Justice for a preliminary ruling. It referred the following questions to the Court of Justice for a preliminary ruling:

1. Are the principle of effectiveness set out in the case-law [of the Court of Justice] of the European Union and the principle of effective judicial protection enshrined in Article 47 of the Charter of Fundamental Rights of the European Union to be interpreted as not permitting a national procedural rule such as Article 133(1) of the Code of administrative procedure which makes jurisdiction for administrative disputes concerning the implementation of the European Union's common agricultural policy dependent solely on the seat of the administrative authority which adopted the contested administrative act, considering that that rule does not take into consideration the place in which the properties are located and the place of residence of the person seeking justice?

2. Is the principle of equivalence set out in the case-law of the Court of Justice of the European Union to be interpreted as not permitting a national procedural rule such as Article 133(1) of the Code of administrative procedure which makes jurisdiction for administrative disputes concerning the implementation of the European Union's common agricultural policy dependent solely on the seat of the administrative authority which adopted the contested administrative act, if account is taken of paragraph 19 of the transitional and final provisions of the Law amending and supplementing the Code of Administrative Procedure (which concerns jurisdiction for domestic administrative disputes concerning agricultural land)?

According to the referring court, an administrative practice has become established in Bulgaria under which acts of the paying agency in connection with the common agricultural policy must be adopted by the Direktor, located in Sofia, irrespective of the regional structure to which the application was made and where the agricultural parcels in respect of which the aid is requested are located. Article 133(1) of the APK therefore requires the Administrativen sad Sofia-grad to rule on all the actions directed against acts of the Direktor. Thus, all disputes concerning aid to farmers under the schemes and measures of the common agricultural policy are concentrated on the referring court. ${ }^{25}$

The referring court thought that the view that the proceedings before it were complicated on account of the remoteness of the agricultural parcels concerned by the Direktor's decision of October 2, 2011. According to that court, the collection of evidence, the production of experts' reports and the

\footnotetext{
${ }^{25}$ Case C-93/12, ET Agrokonsulting-04-Velko Stoyanov v Izpalnitelen direktor na Darzhaven fond "Zemedelie" - Razplashtatelna agentsia, para. 30 (CJEU, June 27, 2013).
} 
inspection of properties, which are often hundreds of kilometres from the city of Sofia, were liable to be delayed and rendered more costly, which would adversely affect the right of farmers, described by that court as a "vulnerable social group", to an effective remedy. The Administrativen sad Sofia-grad raised the issue of whether the principle of equivalence was compatible with a national rule under which jurisdiction for administrative disputes concerning substantive rights derived from European Union law depends solely on the seat of the administrative authority which adopted the contested administrative act. In this connection, the referring court observed that the general rule on territorial jurisdiction in Article 133(1) of the APK did not take account of the location of the agricultural land concerned, unlike the special rule on territorial jurisdiction provided for in paragraph 19 of the transitional and final provisions of the law amending and supplementing the APK in the case of acts adopted under the ZSPZZ.

In the Court's analysis, it appeared that there were considerations linked in particular to the proper conduct of the procedure which supported a finding that the application of a national jurisdiction rule, such as that set out in Article 133(1) of the APK, which results in concentrating before a single court the disputes relating to decisions of a national authority responsible for the payment of agricultural aid under the common agricultural policy, does not infringe the principle of effectiveness. ${ }^{26}$

The answer given to the questions referred was that European Union law, in particular the principles of equivalence and effectiveness and Article 47 of the Charter, does not preclude a national rule of jurisdiction such as that in Article 133(1) of the APK, which results in conferring on a single court all disputes relating to decisions of a national authority responsible for the payment of agricultural aid under the European Union common agricultural policy, provided that actions intended to ensure the safeguarding of the rights which individuals derive from European Union law are not conducted in less advantageous conditions than those provided for in respect of actions intended to protect the rights derived from any aid schemes for farmers established under national law, and that jurisdiction rule does not cause individuals procedural problems in terms, inter alia, of the duration of the proceedings, such as to render the exercise of the rights derived from European Union law excessively difficult, which is for the referring court to ascertain. $^{27}$

The importance of Agrokonsulting would have been difficult to grasp at first sight, had it not been commented by the referring judge herself. Ms.

\footnotetext{
${ }^{26}$ Ibid, para. 58 .

${ }^{27} \mathrm{Ibid}$, operative part.
} 
Aglika Adamova, judge at the Administrativen sad Sofia-grad, pointed out, as did Mr. Advocate General Bot, that the Court was ruling for the first time on the compatibility of a national rule governing administrative jurisdiction was compatible with Article 47 of the Charter. The reasoning of the judgment imposes on national courts an obligation to assess if national rules on jurisdiction and/or national procedure render the exercise of the rights derived from European Union law excessively difficult. This means in practice, according to Ms. Adamova, that both the applicant and the national court may disapply an imperative procedural provision governing jurisdiction under national law by relying on Article 47 of the Charter and on the principles equivalence and effectiveness. ${ }^{28}$ This would be an application of the principle of supremacy of EU law over national law, whereby the latter would prevail over imperative procedural norms governing jurisdiction. The referring judge has drawn immediate consequences from the judgment by allowing the applicants in the main proceedings to declare if the national rule governing jurisdiction rendered the exercise of their rights conferred by European Union law excessively difficult or impossible in practice. On that basis, she would be prepared to rule on a new conflict of jurisdiction in the same dispute. ${ }^{29}$

Another issue which had to be resolved was until which moment such a declaration can be made by the applicants in the main proceedings. According to Ms. Adamova, the declaration may be made even after the end of the oral procedure, and the parties should be instructed to that effect by civil and administrative judges, from their own motion. If the national judge refuses to consider a plea alleging lack of jurisdiction under national procedural law, that failure to consider the plea would amount to an obvious and manifest infringement EU law allowing the parties to succeed in an action for damages against the national court under the Köbler case law (C$224 / 01) .{ }^{30}$

\section{CONCLUSION}

It is clear from the above that the Court may be asked to make a ruling on the compatibility with union law of specific provisions of national law. This is a fundamental feature of EU law, although it is well-established that in proceedings brought under Article 267 TFEU:

\footnotetext{
${ }^{28}$ A. Adamova, Podsadnostta po APK sreshtu zashtitata na materialni prava, koito proiztichat ot pravoto na ES, tom VII, EVROPEYSKI PRAVEN PREGLED 214 and seq. (2013).

${ }^{29}$ Ibid, para. 40, at 215.

${ }^{30} \mathrm{Ibid}$, at 216-217.
} 
...the Court has no jurisdiction to apply the rules of [Union] law to a specific case or, consequently, to classify provisions of national law with respect to such a rule. It may, however, provide the national court with an interpretation of all relevant provisions of [Union] law which might be useful to it in assessing the effects of such provisions on national law. ${ }^{31}$

In fact, this case law applies to the scope of interpretation of provisions of EU law. Whenever the Court is specifically asked if a national provision contravenes or is compatible with EU law, it will rule on that question. Sometimes, it is particularly explicit as regards the compatibility issue: In case C-124/12 (another Bulgarian case), the Court ruled that it is for the referring court to interpret the provisions of domestic law at issue in the main proceedings, so far as possible, in accordance with European Union law. Where such an interpretation proves impossible, the referring court is required to set aside those provisions ${ }^{32}$.

Byankov and Agrokonsulting are important cases for the theory of EU law. They allow the latter to go one step further towards the assessment of the compatibility of national law with EU law.

\footnotetext{
${ }^{31}$ See, in particular, the judgment in Case 37/86 Van Gastel, née Coenen v Rijksdienst voor Werknemerspensioenen and Rijkskas voor Rust- en Overlevingspensioenen [1987] ECR 3589, paragraph 8).

${ }^{32}$ Case C-124/12, AES-3C Maritza East 1 EOOD v Direktor na Direktsia 'Obzhalvane i upravlenie na izpalnenieto' pri Tsentralno upravlenie na Natsionalnata agentsia za prihodite, Plovdiv (CJEU July 18, 2013), operative part.
} 